Acta Horticulturae et Regiotecturae 1

Nitra, Slovaca Universitas Agriculturae Nitriae, 2019, pp. 1-7

\title{
SMALL SACRAL CHRISTIAN ARCHITECTURE IN THE CULTURAL LANDSCAPES OF EUROPE
}

\author{
Attila TÓTH ${ }^{1,4 *}$, Axel TIMPE${ }^{2}$, Richard STILES ${ }^{3}$, Doris DAMYANOVIC ${ }^{4}$, István VALÁNSZKI ${ }^{5}$, \\ Alena SALAŠOVÁ ${ }^{6}$, Agata CIESZEWSKA ${ }^{7}$, Elizabeth BRABEC 8,9 \\ ${ }^{1}$ Slovak University of Agriculture in Nitra, Slovakia \\ ${ }^{2}$ RWTH Aachen University, Germany \\ ${ }^{3}$ Vienna University of Technology (TU Wien), Austria \\ ${ }^{4}$ University of Natural Resources and Life Sciences (BOKU), Austria \\ ${ }^{5}$ Szent István University, Hungary \\ ${ }^{6}$ Mendel University in Brno, Czech Republic \\ ${ }^{7}$ Warsaw University of Life Sciences (SGGW), Poland \\ ${ }^{8}$ University of Massachusetts Amherst, USA \\ ${ }^{9}$ Czech University of Life Sciences, Prague, Czech Republic
}

\begin{abstract}
Though often overlooked due to its scale, small sacral Christian architecture has a significant importance in cultural landscapes in Europe and beyond. It represents a shared international cultural heritage and is significant in its diversity, distribution and abundance across cultural landscapes. The tradition of the artistic depiction of the cross in Christianity dates back to the $4^{\text {th }}$ century AD. The first monuments in the form of crosses were placed in open landscapes in Scotland in the $7^{\text {th }}$ century. The most important period for the spread of small sacral architecture of Catholic origin in eastern Europe was during the Baroque, thus most of the preserved small sacral monuments date back to the late $17^{\text {th }}, 18^{\text {th }}$ and $19^{\text {th }}$ centuries. They are often accompanied by monumental single trees or a compositionally organised group of trees and create a sacred composition of nature and culture. They have become important landmarks, indicators of place and landscape features of spatial organization, representing a significant historical legacy and cultural heritage for future generations. This article elaborates on the origin, historical development and landscape values of small sacral Christian architecture, as well as their relation to separate natural monuments or natural features that create part of the sacral composition, such as memorial trees growing around them. This article introduces the topic of sacral architecture and its contribution to the character and identity of European cultural landscapes.
\end{abstract}

Keywords: cultural heritage; history; landscape; sacral architecture; trees

Sacral architecture has been an inherent component of European cultural landscapes for centuries, if not millennia. Religious structures and features of different scales and sizes have co-formed the traditional visual character of European landscapes, becoming an important cultural heritage shared by many regions and ethnical groups across and beyond Europe - from standing stones to more recent Christian expressions of rural churches that dominate wide open rural landscapes, calvaries in designed landscapes or cathedrals in historical urban centres (Fekete and Van den Toorn, 2018). However, there is another significant cultural heritage, though small in its size, but significant in its presence and distribution in the landscape - small sacral architecture.

Small religious monuments are mostly of local importance as individual objects, but when perceived as a collective heritage across regions, their importance becomes internationally significant. They are small visual manifestations of shared cultural and historical values, with a significant religious and spiritual legacy, which impart meaning to the landscape. Compared to large monuments, small sacral monuments spread the historical legacy of everyday life of "little people" as suggested by Braun (2013). They have survived many landscape changes across decades and even centuries and today are part of the visual character of the landscape (Sedláček et al., 2016) with a high potential in contemporary rural development and restoration of rural landscapes (Tóth and Feriancová, 2016; Supuka and Billiková, 2018) as well as for tourism and local economic development. They should be therefore documented in land consolidation projects as small-scale cultural monuments and sites, in order to preserve them in the landscape (Muchová and Leitmanová, 2016). As a network of important cultural monuments and sites, their preservation is considered of critical importance in international documents such as the Venice Charter (ICOMOS, 1964), and the European Landscape Convention (Council of Europe, 2000). 
In many regions and local communities, where Christianity is still very vivid and actively practiced, small sacral monuments maintain a significant religious importance and symbolic meaning. In some places new elements of small sacral architecture are erected and consecrated, particularly in rural areas. In other regions, the understanding and recognition of religious meaning is declining. In those areas, where the monuments have become "disconnected heritage," Katzberger (1998) suggests that it should be replaced by reverence, respect and understanding for the values perceived by past cultures and for their importance to local landscapes and their identity.

Small sacral monuments, whether or not registered as cultural heritage in the landscape, deserve the attention of professionals as well as laypeople, with the aim to protect, maintain, restore, preserve and adequately present them in their landscape settings (Vošková et al., 2014). This special issue of Acta Horticulturae et Regiotecturae dedicated to Christian religious architecture in diverse cultural landscapes across Europe recognises their heritage value and historical legacy. The aim of this issue is to put the subject of small sacral architecture on the international cultural landscape agenda and pursue cross-border and inter-regional

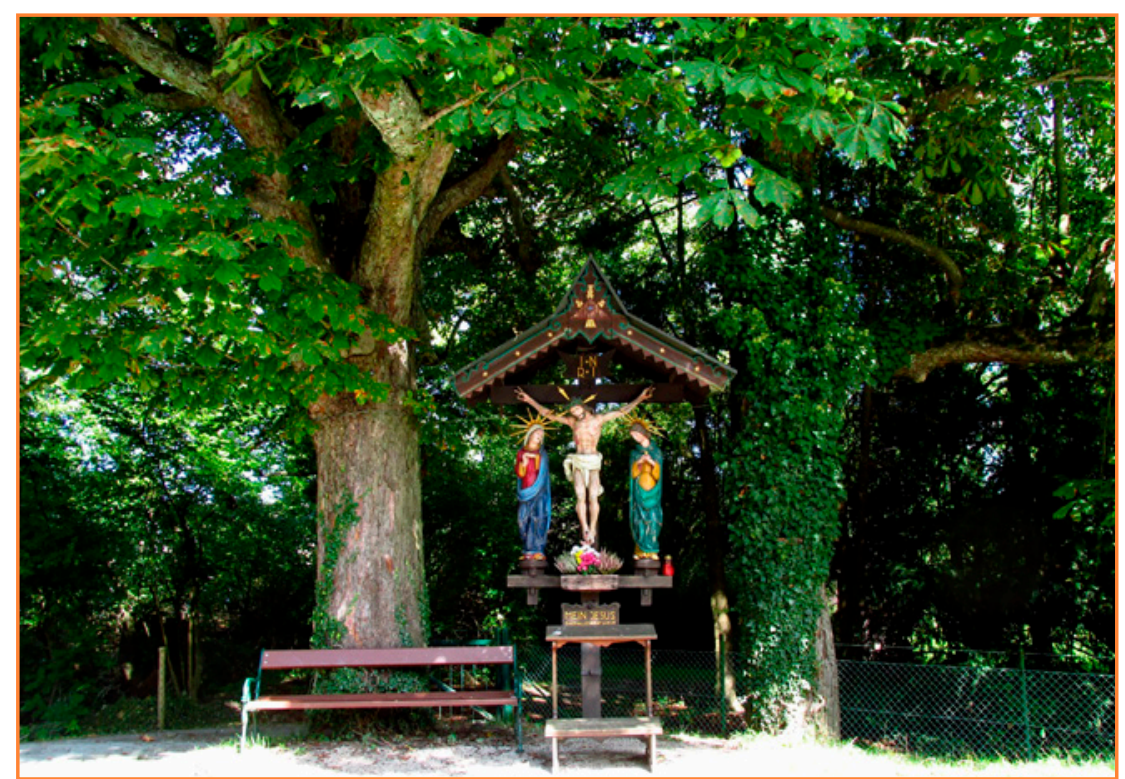

Figure 1 A wayside cross in Gmunden (Austria) framed by two horse chestnuts (Aesculus hippocastanum L.) Source: Tóth, 2017 cooperation in research, preservation and sustainable use of small religious monuments and sites.

\section{Material and method}

This paper relies on an extensive review of the literature on small sacral architecture. The literature review work was conducted mainly in university libraries at the Slovak University of Agriculture in Nitra, Vienna University of Technology and RWTH Aachen University. Most of the literature has local or regional coverage and was written in national languages, especially German, Slovak and Czech. The methodology of the work consisted of:

1. a thorough review of the existing literature noting gaps in the research;

2. field mapping in Slovakia, Austria, Germany, Hungary, Czechia and Poland;

3. analysis, interpretation and evaluation of the findings;

4. international knowledge exchange;

5. review and editorial work on the papers submitted to this special issue.

The selection of the six European countries used as reference regions is based on their cultural, historical and religious similarities. Austria, Hungary,
Slovakia and Czechia, as well as parts of Poland were part of one empire (the 'Habsburg Empire' of different designations from 1526 to 1918) and there are linguistic and other cultural similarities between Germany and Austria.

Considering regional diversities, it is necessary to highlight the fact that small sacral monuments are common in traditional Catholic regions in Europe. For instance, in Austria, Slovakia and Poland, the Catholic population has a strong representation in all administrative regions, while in Germany Catholics are mainly concentrated in Southern and Western parts of the country. In Hungary, Catholic regions cover most of Western and Central part of the country, while in Czechia, they appear throughout the country, a dominance which reflects the seat of the Holy Roman Emperor in Prague as well as the primacy of Catholicism throughout the regions of Bohemia and Moravia during the Habsburg reign. Eastern parts of Poland, Slovakia and Hungary have also been marked by Orthodox culture and traditions, which has had influence on the overall style of Christian sacral architecture, including small monuments in the landscape. Beyond these areas, the most important architectural styles, as well as the Christian religion and culture have had a pan-European spread and importance.

\section{Results and discussion}

The results and discussion consist of four main chapters dedicated to:

1. the origin and historical development of Christian fine art and religious architecture in Central European cultural landscapes;

2. the landscape aspects of small sacral architecture;

3. the linkage between natural and cultural monuments in the form of sacral monuments and trees;

4. a brief overview of the papers in this issue of Acta Horticulturae et Regiotecturae. 
When and where has it started? A brief history of Christian small sacral architecture in Europe

The cross as the symbol of Jesus Christ's crucifixion was not depicted in the first three centuries AD. It has occurred in Christian symbolism approximately since the $4^{\text {th }}$ century, when the liturgical worshipping of the cross started in Catholic services. The cross was also used as a symbol in late ancient and medieval battles.

According to a legend, the Roman emperor Constantine I (272-337) marked his soldiers' shields with a cross-like sign (Chi-Rho or Labarum) in the Battle of the Milvian Bridge (312 AD). Labarum has been used since then in Christian symbolism as a reference to the crucifixion of Christ. In the Early Middle Ages, the cross was depicted on crowns and orbs of Christian rulers and it became a symbol of victory, power, and reign, which was also used in the Crusades.

One of the first common uses of the cross as a symbol was on rooftops of church towers. The first crosses in open spaces or open landscapes occurred in Scotland and Ireland, and date back to the $7^{\text {th }}$ century. Later they appeared also on the European continent, mainly as border crosses. They became more abundant since the $14^{\text {th }}$ century, especially in the form of wooden or stone crosses for atonement, remembrance and protection (Beckers, 1981). In the Middle Ages, the architectural typology of small sacral monuments in the landscape became more diversified.

In addition to crosses, other forms such as small wayside shrines and columns occurred in towns, villages and open spaces throughout the landscape. In the Gothic period of the High Middle Ages, another Christ interpretation appeared. Instead of salvation and victory, it started to focus on Christ's suffering, crucifixion and death.This shiftfrom thetranscendental glory to the more tangible pain and suffering caused humanisation of faith. Depictions of Pieta from the Late Middle Ages show the pain and suffering of Christ and make the crucified Christ look more human and closer to people suffering at that time from plague outbreaks (Langen and Cormann, 1988). In Late Middle Ages, during the counter-reformation, the occurrence of small sacral monuments significantly increased (Liszka, 2007). According to Katzberger (1998) their abundance was further enhanced by governmental decrees, which ordered their construction as a symbolic celebration of military victories (e.g. the recapture of the Hungarian Raab Fortress from the Turks in 1598) or as a commemoration of acts of reconciliation (e.g. the Peace of Westphalia in 1648). However, there were also reversals, for instance during Napoleon's reign when the Rhineland was under French occupation (17941814), and it was ordered to remove all small sacral monuments to the left of Rhine during secularisation that started in 1803 (Braun, 2013).

The Baroque period (late $17^{\text {th }}$ through mid- $18^{\text {th }}$ centuries) made one of the most significant contributions to Christian art and also small sacral architecture. Baroque as a style became a visual expression of counterreformation in religious architecture. Crosses were richly decorated and became common elements in Baroque cultural landscapes that were used as stations for religious pilgrimage, liturgical rituals or harvest processions (Löw and Míchal, 2003; Kopeček et al., 2015). The Baroque

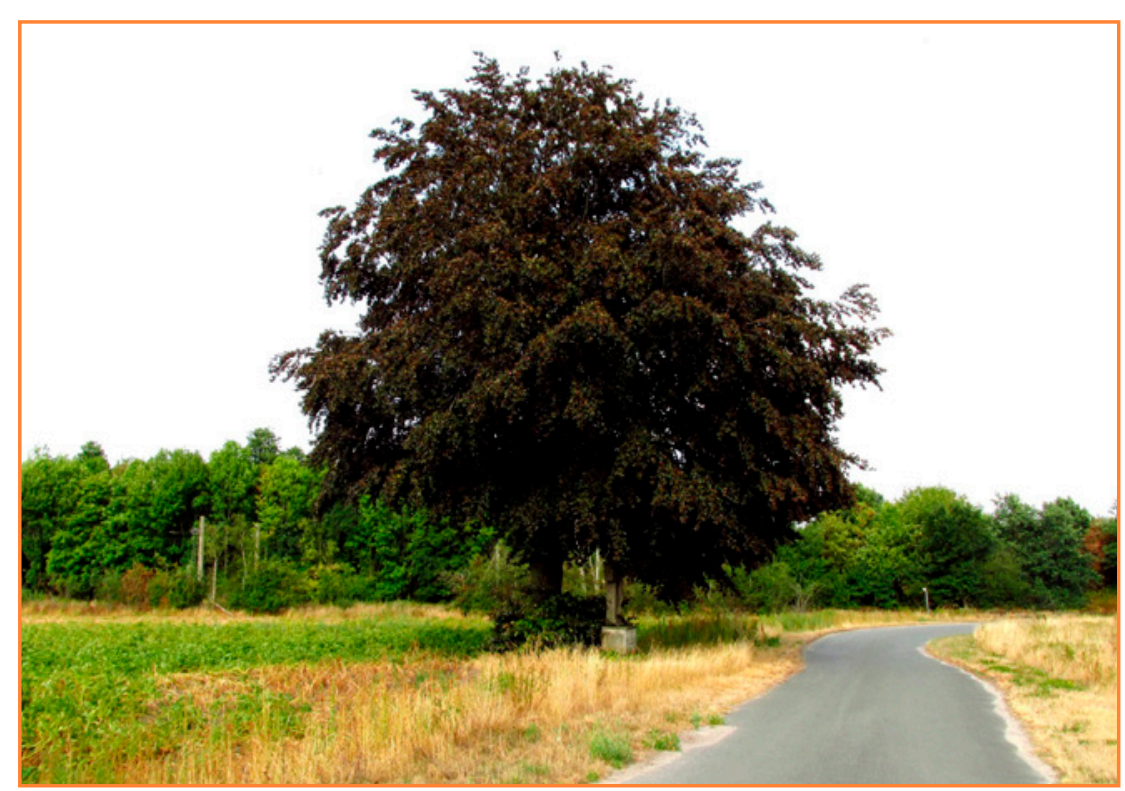

Figure 2 A commemorative wayside cross in the municipality of Emsbüren (Germany) erected after World War II for the memory of a soldier killed in action during the war. The cross is accentuated by a red-leaved common beech (Fagus sylvatica L.). Both, the cross and the tree survived land consolidation in the 1990 s

Source: Tóth, 2018 period also brought a new form of Christian art expression in the open landscape - figural monuments - such as sculptures and reliefs placed on the top of wayside columns and shrines or in their exposition niches (Langen and Cormann, 1988, Katzberger, 1998). The significant Marian-cult (Immaculata or Pieta) and veneration of saints provided manifold motives for figural expressions in outdoor spaces.

In regions with consolidated Catholic faith after the Thirty Years'War (1618-1648) the century between 1680 and 1780 is considered the peak of the creation of small sacred architecture in the landscape (Breuing, 1985). The $18^{\text {th }}$ century was characterised by the euphoria from the victory over the Turks and the Plague outbreaks. Saint John of Nepomuk, whose statues were placed mainly on riversides and bridges (Liszka, 2007) became the most common and widespread singular figural motive in Austro-Hungarian Monarchy (Katzberger, 1998). Another abundant motive was represented by plague columns crowned with statues of the Holy Trinity, which were raised on squares in village and town centres as a gratitude for the end of the plague outbreak in 1713 (Katzberger, 1998). Baroque-style crosses were created even in the first half of the $19^{\text {th }}$ century, 
e.g. from blue or shelly limestone, as stonemasons were trained in the style of the Baroque period and did not change their style until Classicism, although the ornamental decoration became gradually simpler.

The mid- $^{\text {th }}{ }^{\text {th }}$ century brought a significant change in the style of village, field and roadside crosses. Historicism, including the neo-Gothic monuments were traditionally constructed mainly from locally available materials (e.g. wood, sandstone, limestone, travertine) or materials imported from nearby regions. Metals (e.g. cast iron or tin plates) started to be used in the mid- $19^{\text {th }}$ century. In regions where there was no natural source of stones, wood remained the main material for constructing small sacral architecture. Neo-Gothic crosses were constructed until the beginning of World War I.

After World War I, a new change of style followed - the modern cross with its simple, sober form. This change brought also a new material concrete; however, sandstone, wrought iron and wood remained in use. The modern cross depictions were strongly influenced by the experience and suffering in the world wars. New religious monuments were placed in the landscape also in the second half of the $20^{\text {th }}$ century. In some cases it was style, broke through. Small sacral

old cemetery crosses that were re-used in public open spaces as monuments. Some small religious monuments were moved to other locations due to urban development, construction of motorways, or destruction of settlements for brown coal mining (Langen and Cormann, 1988) or due to construction of water reservoirs that required flooding of large areas. Many valuable small sacral monuments are concentrated in old cemeteries. One of the most remarkable Slovak architects - Dušan Jurkovič (1868-1947), founder of Modern Architecture in Slovakia who integrated vernacular architecture into his projects, designed 32 cemeteries in 1916 and 1917 for soldiers fallen in World War I in Galicia. These cemeteries are full of crosses with excellent and very specific artistic representations and they are protected by law under the Act on Monuments (Dulla, 2002).

\section{Small sacral architecture in cultural landscapes}

Small sacral architecture in the landscape, such as wayside crosses, columns, shrines, small bell towers, small chapels, statues and figural compositions are religious evidences of the Christian faith. They are objects of remembrance, prayers, atonement, gratitude, procession or mission (Matáková, 2012; Kopeček et al., 2015). Besides their obvious religious

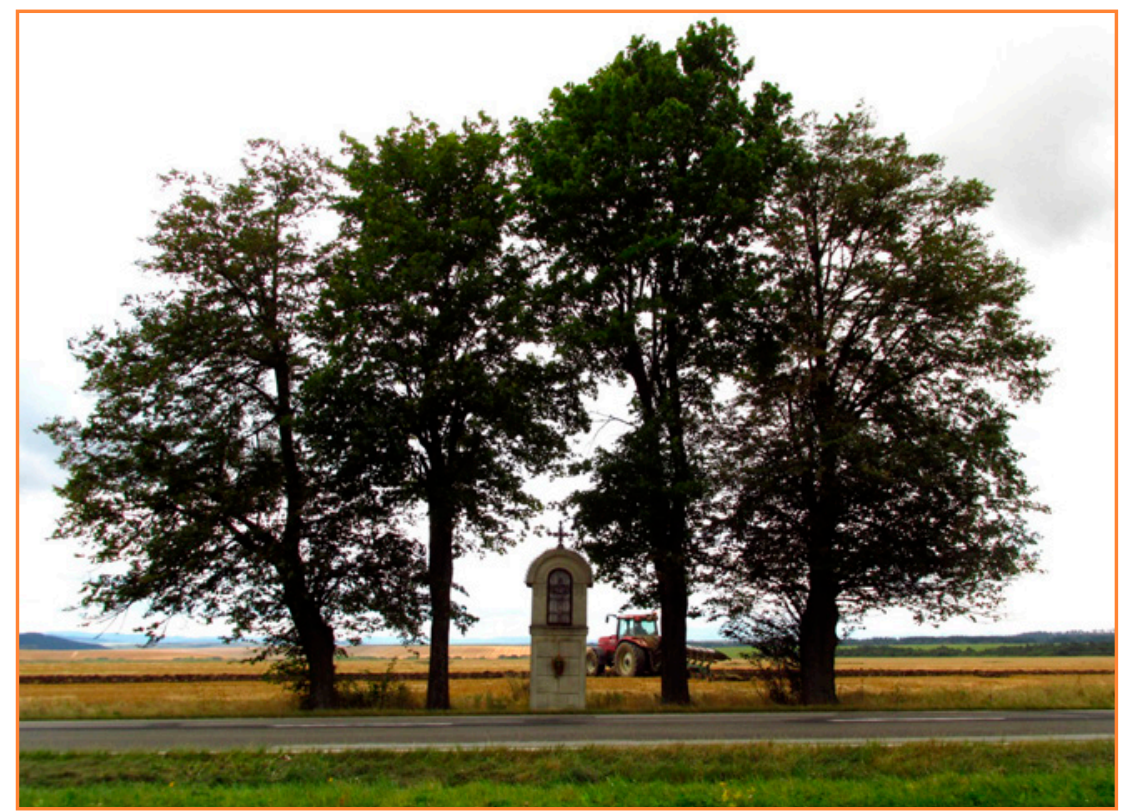

Figure 3 A roadside shrine in Spišská Belá (North-Eastern Slovakia) with 3 smallleaved limes (Tilia cordata Mill.) and a Norway maple (Acer platanoides L.) Source: Tóth, 2017 function and meaning, small sacral sites have served also as guideposts and way-markers, especially in flat landscapes with no or few trees, where they were visible for pedestrians and carters. Thus, the multifunctionality of these sites was much more a rule than an exception (Langen and Cormann, 1988; Braun, 2013).

Small sacral Christian monuments, such as wayside crosses, shrines, tabernacles, columns, chapels, figural monuments and other architectural forms from the Gothic, Renaissance, Baroque and later periods are witnesses of the piety of the local population throughout the last eight centuries. They have become integral features of cultural landscapes and have co-formed their visual characters and features (Katzberger, 1998; Matáková, 2012; Pluta, 2018). Small religious monuments and structures occur in diverse spatial settings - in open and built-up/in rural and urban/in everyday and exceptional landscapes (Tóth and Verešová, 2018). In the open landscape they were placed at significant points: at crossroads, at municipal borders and field boundaries (Türk, 1979), at the edges of villages and towns, on small hills, in vineyards, forests and at boundaries of arable fields or family farms (Creutz, 2005; Verešová and Supuka, 2013). Some monuments located on or at family farms in rural landscapes were originally gravestones in cemeteries that were later moved to the property (Türk, 1979). In built-up areas, small sacral monuments were raised mainly on squares and streets, in churchyards and cemeteries (Halajová and Kubišta, 2015; Halajová et al., 2016) or on walls of buildings and in their small niches (Langen and Cormann, 1988) and currently they are present also in public green and open spaces (Trojanowska, 2018). They were used for instance in Corpus-Christi Processions or in Summer Field Processions for good harvest and protection against bad weather (Braun, 2013). Crosses exposed in agricultural landscapes also gained another function - they were supposed to keep away bad weather, especially hailstorms, from the arable land or to defend the villages against evil spirits and demons. Thus faith and superstition were often very close to each other or even interwoven (Langen and Cormann, 1988). In some 
cases, small religious monuments were used to divide long pedestrian routes between two settlements into smaller segments and served as rest and prayer sites in the open landscape (Katzberger, 1998).

Small sacral architecture present distinctive accents in impressive landscape sceneries (Kitlitschka, 1987) and reflect traditional architecture, arts and crafts of a region (Štěpánková and Feriancová, 2011). They spread the spiritual message of churches and chapels into the open landscapes and thereby form a continuous spiritual legacy and identity of local cultural landscapes (Kopeček et al., 2015). Schneeweis (1987) refers to them as Jewels of the Danubian Sacral Landscape, which according to Katzberger (1998) decorate and revive the landscape - be it hilly regions with vineyards or wide open flatlands with fertile arable land. Burggraaff and Kleefeld (1998) define them as point elements in cultural landscapes of religious and cult character.

\section{Joint monuments of nature and culture}

Trees, given their longevity and impressive spatial presence, have always been perceived, adored and worshipped by people as natural monuments in cultural landscapes (Rózová et al., 2015) and have become important features of historical landscape structures (Supuka et al., 2015). They were planted as solitary trees, at sacral monuments, as tree roundels or as lines of trees and alleys (Semanová, 2015). Trees were often planted as complementary compositional elements next to sacral buildings and small sacral monuments.

In Roman and Early Gothic periods, sacral structures were normally standalone landmarks without trees. The first solitary trees were presumably planted at the end of the Gothic period (Semanová, 2015). In Slovakia, it was mainly lime (Tilia sp.). At the beginning of Renaissance, solitary trees were still very common, but later stages of this period brought symmetrical compositions of two trees. The Baroque period brought a significant enhancement of trees at sacral architecture and the $19^{\text {th }}$ century was specific for a marked enrichment of tree species diversity (Semanová, 2015).
Trees emphasised small monuments in the landscape, while forming a peculiar connection between earth and sky. There are usually one or two trees at a monument, but also more complex compositions with 3, 4 or 5 trees occur (Assmann, 1979; Tóth and Verešová, 2018). A tree or a group of trees situated directly at a small religious element not only harmoniously integrates it into the landscape, but at the same time enhances its visibility from a distance (Katzberger, 1998). Some of the most common tree species planted at small sacral monuments are limes - Tilia cordata Mill. and Tilia platyphyllos Scop. and horse chestnuts - Aesculus hippocastanum L. (Tóth and Verešová, 2018), but also other genera such as oaks - Quercus sp. and ashes Fraxinus sp. or black locust - Robinia pseudoacacia L. occur (Creutz, 2005, Semanová, 2015).

The selected tree species usually had an important cultural and symbolic meaning. Especially oaks and limes have a strong cultural and symbolic meaning. Quercus robur L. for instance is known in Germany as the Deutsche Eiche (German Oak) and it was also the most worshipped tree in Slavic mythology and plant cult. Limes were planted on important sites, such as open-air courts or village squares, which might explain their use to highlight important sites and elements

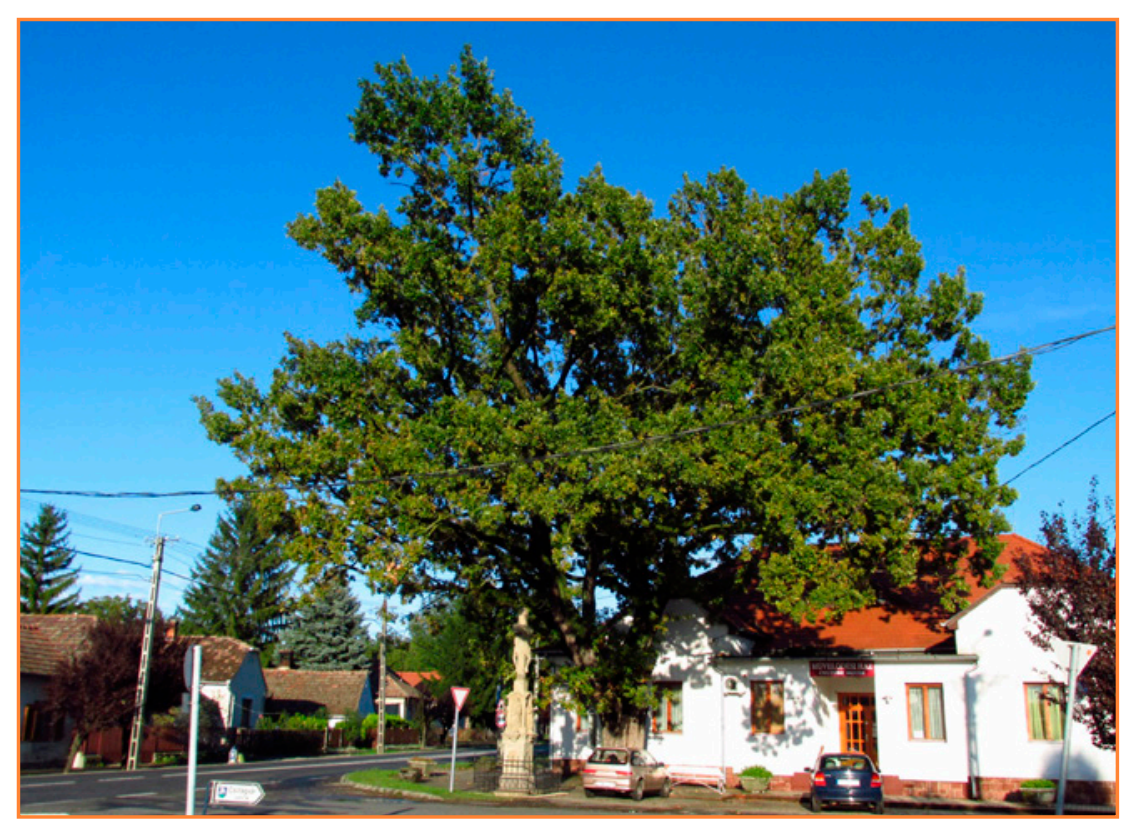

Figure 4 A neogothic roadside cross in Balatonszentgyörgy (Hungary) with a monumental common oak (Quercus robur $\mathrm{L}$.)

Source: Tóth, 2017 in the open landscape. Horse chestnut was introduced to Central Europe in the Baroque period as one of the first exotic species (Löw and Míchal, 2003) with impressive blossoming, which could explain why it is so commonly used at small sacral monuments from Baroque and subsequent periods (Tóth and Feriancová, 2015; Semanová, 2015; Tóth, 2017). In many cases the tree is the main landmark and, in Germany, it has inspired the local name of the site - e.g. "Lindenkreuz", "An der alten Linde", "An den drei Lindchen" and similar - all related to limes (lindens)/ Tilia sp. (Langen and Cormann, 1988).

\section{The Acta Horticulturae et Regiotecturae thematic issue on sacral architecture in cultural landscapes}

This thematic issue focuses on the linkage between small sacral architecture and the cultural landscape. The introductory paper discusses the origin, historical development, landscape features and heritage values of small sacral architecture in cultural landscapes with a particular focus on Europe (Tóth et al., this issue). Calaza-Martínez et al. (this issue) elaborate on sacred landscapes in Galícia (Spain), with a particular focus on small religious architecture and its symbolical character. Stara and Tsiakiris (this issue) explore the 
relations between trees and urban open spaces, with a particular focus on oriental plane (Platanus orientalis L.) as well as other threatened monumental trees that grow in central squares and churchyards in North-Western Greece, while highlighting their sacred and emblematic features. Christianity, its traditions, art and architecture have not only shaped cultural landscapes in Europe, they were also "exported" to the "New World" - former European colonies and have influenced architecture and fine art overseas. Heavers (this issue) elaborates on the impact of imported trees and medieval European sculpture that has marked sacred ground at the Washington National Cathedral (USA). Lubiarz et al. (this issue) bring us back from USA to Europe and target our focus on small roadside sacral structures in Borzechów Commune (Lublin Region, Poland), while highlighting their dendroflora. Halajová et al.; Bihuňová and Michalica; and Fusková and Fuska (this issue) present some of the first findings of field mapping conducted within the research project VEGA 1/0371/18 SacralArch (2018-2020) coordinated by Tóth at the Department of Landscape Architecture at SUA Nitra. They focus on the Spiš (North-East), Senica (North-West) and Tríbeč (West) regions in Slovakia. The collection of articles is concluded by Netsch and Gugerell (this issue) who elaborate on one of the possible ways of preserving sacral architecture in European cultural landscapes - through the re-use of churches in Dutch urban and rural landscapes that has had a significant tradition in the Netherlands recently.

\section{Small sacral monuments as part of a wider phenomenon - outlooks for further research}

Small sacral monuments can be considered from two different points of view: firstly, there are the artefacts themselves, which are perhaps what the historic monuments conservation discipline is primarily concerned with, but secondly there is the fact that they can often be said to be something else, too - markers of special places in the landscape. Places where they are found may often in some way be just as significant as the artefacts themselves. These may either be places of memory relating to a relatively recent event, or they may be located at places in the landscape which have an older significance.

Christian monuments are more recent and perhaps a particularly European expression of an older phenomenon. One can think, for example, of 'standing stones' in Western Europe (from Stonehenge downwards) or 'rune stones' in Scandinavia. More recently, 'land art' and environmental sculpture have also tried to give special meaning to places or to respond to the existing, innate character and atmosphere of special places in the landscape. The 'New Milestones' project of the UK environmental charity Common Ground represents a particularly interesting example of this approach (Common Ground, 2019).

Thus, there is a great potential of expanding the topic of this article, while including also other forms of marking special places in the landscape. This may be a forward look towards new research questions and joint initiatives.

\section{Conclusion}

This paper contributes to the internationalisation of the scientific knowledge in the field of (small) sacral architecture in cultural landscapes. It makes an effort to put together national, regional and local knowledge mostly presented in different national languages and aims at generalising the findings in order to enrich the European state of the art in this field. This thematic issue of Acta Horticulturae et Regiotecturae has collected and linked knowledge from diverse regions of Europe (Slovakia, Germany, Austria, Hungary, Czechia, Poland, Spain, Greece, the Netherlands) and beyond (USA, North America). Our aim for the future international exchange is to achieve a more robust geographic and also cultural coverage, while reaching further out within and beyond Europe and covering not only Christian, but also other religious cultures that have left an important footprint on cultural landscapes of diverse regions.

\section{Acknowledgement}

This paper as well as the editorial work of this issue are outcomes of the research projects VEGA 1/0371/18 SacralArch: Preservation of the Historical Legacy and Architectural Diversity of Small Sacral Structures in Cultural Landscapes of Slovakia; 07-GA SPU-17 Preservation of the Historical Legacy of Small Sacral Architecture in Rural Cultural Landscapes of Dolné Považie and KEGA 001SPU4/2017 Ecosystem Services of Green Infrastructure.

Fieldwork and literature review were funded by the Ministry of Education, Science, Research and Sport of the Slovak Republic, the Federal Ministry of Education and Research of Germany within the Green Talents Programme, and the Austrian Federal Ministry of Education, Science and Research within the Action Austria-Slovakia Programme.

\section{References}

ASSMANN, D. 1979. Das Kleindenkmal in der Kulturlandschaft. In Umweltgestaltung als kulturelle Aufgabe. Linz : Österreichisches Forum für Umweltschutz und Umweltgestaltung, 1979, pp.12-15. BECKERS, H. 1981. Eilendorfer Flurdenkmäler. Aachen-Eilendorf : Hubert Beckers Eigenverlag, 1981, 84 p.

BRAUN, L. 2013. Kleindenkmäler in Eschweiler: Wegekreuze, Bildstöcke, Kapellen, Missionskreuze, Gedenksteine. Eschweiler : Eschweiler Geschichtsverein e.V., 2013, 132 p. ISBN 978-3-9816072-1-5.

BREUING, R. 1985. Barocke Wegbilder und Kapellen im Kreis Steinfurt. Steinfurt : Schriftenreihe des Kreises Steinfurt, Beiträge zu Geschichte, Kultur und Wirtschaft, Band 4, 1985, 655 p.

BURGGRAAFF, P. - KLEEFELD, K.D. 1998. Historische Kulturlandschaft und Kulturlandschaftselemente. Bonn : Bundesamt für Naturschutz, Angewandte Landschaftsökologie, 1998, 320 p.

COMMON GROUND. 2019. New Milestones [online] [cit. 2019-04-23]. Available at: https://www.commonground.org.uk/new-milestones CREUTZ, A. 2005. Gedenksteine und Wegekreuze im Grenzraum des oberen Göhltales : Spuren der Vergangenheit in Aachen-SiefWalheim-Raeren-Eynatten-Hauset-Hergenrath. Aachen: Helios, 2005, 378 p. ISBN 3-938208-10-4.

DULLA, M. 2002. Military cemeteries of Western Galicia. Bratislava : Academy of Fine Arts and Design, 2002, 135 p. ISBN 80-88675-80-4. FEKETE, A. - VAN DEN TOORN, M. 2018. Sacred Eye-Catchers. In Teka Komisji Urbanistyki i Architektury Pan Oddział w Krakowie Urbanity and Architecture Files TOM, vol. XLVI, 2018, pp. 303-311. ISSN 0079-3450. 
HALAJOVÁ, D. - KUBIŠTA, R. 2015. Some Aspects of Greenery Restoration and Maintenance Management of Woody Plants in Cemeteries in Nitra, Slovakia. In Acta Horticulturae et Regiotecturae, vol. 17, 2015, no. 2, pp. 29-34.

HALAJOVÁ, D. et al. 2016. Memorial Landscapes \& Outdoor Recreation: Evidence of Landscape Multifunctionality by the Case Study Jankov Vŕšok, Slovakia. In Public Recreation and Landscape Protection - with Nature Hand in Hand. Brno : Mendel University in Brno, 2016, pp. 105-113. ISBN 978-80-7509-408-7.

KATZBERGER,P.1998.Werkeder Bildhauerkunstund Kleindenkmäler in Perchtoldsdorf. Perchtoldsdorf : Verlag der Marktgemeinde Perchtoldsdorf, 1998, 615 p. ISBN 3-901316-15-9.

KITLITSCHKA, W. 1987. Das Flurdenkmal in der Kulturlandschaft. In Denkmalpflege in Niederösterreich: Kleindenkmäler. Wien : Amt der NÖ Landesregierung, 1987, pp. 5-9.

KOPEČEK, P. et al. 2015. Projevy křestanské liturgie v kulturní krajině. Brno : Mendelova univerzita $v$ Brně, 2015, 164 p. ISBN 978-80-7509-387-5.

LANGEN, N. - CORMANN, U. 1988. Kreuze im Jülicher Land. Jülich : Verlag des Jülicher Geschichtsvereins, 1988, 160 p. ISBN 3-9801876-0-8.

MUCHOVÁ, Z. - LEITMANOVÁ, M. 2016. The Register Suggestions: Processing Tool for Land Consolidation Projects. In Acta Horticulturae et Regiotecturae, vol. 19, 2016, no. 2, pp. 32-36.

LISZKA, J. 2007. Archív malých sakrálnych pamiatok "Na slávu Božiu..... In Enviromagazín, vol. 12, 2007, no. 1, pp. 18-21.

LÖW, J. - MíCHAL, I. 2003. Krajinný ráz. Kostelec nad Černými lesy: Lesnická práce, 2003, 552 p. ISBN 80-86386-27-9.

MATÁKOVÁ, B. 2012. Spiritual Values of Rural Landscape in the Czech Republic and Slovakia. In Životné prostredie, vol. 46, 2015, no. 4, pp. 193-198.

PLUTA, K. 2018. Sacrum in the Contemporary Landscape of Warsaw. In Teka Komisji Urbanistyki i Architektury Pan Oddział w Krakowie Urbanity and Architecture Files TOM, vol. XLVI, 2018, pp. 343-360. ISSN 0079-3450.

RÓZOVÁ, Z. - HALAJOVÁ, D. - BIHUŇOVÁ, M. 2015. Symbolism and Healing Power of the Trees. In Životné prostredie, vol. 49, 2015, no. 3, pp. 162-168.

SCHNEEWEIS, E. 1987. Flurdenkmäler als Zeugnisse der Überlieferung. In Denkmalpflege in Niederösterreich: Kleindenkmäler. Wien : Amt der NÖ Landesregierung, 1987, pp. 10-18.

SEDLÁČEK, J. - ŠESTÁK, O. - SLIACKA, M. 2016. Comparison of Digital Elevation Models by Visibility Analysis in Landscape. In Acta Horticulturae et Regiotecturae, vol. 19, 2016, no. 2, pp. 28-31.
SEMANOVÁ, E. 2015. Stromy v kompozičných prvkoch kultúrnej krajiny - niekol'ko poznatkov a skúseností z hladiska pamiatkovej ochrany (na príklade Prešovského kraja). In Životné prostredie, vol. 49, 2015, no. 4, pp. 242-246.

SUPUKA, J. - PEJCHAL, M. - KUCZMAN, G. 2015. Tree Heritage in Cultural Landscape and Dendrological Objects. In Životné prostredie, vol. 49, 2015, no. 3, pp. 131-136.

SUPUKA, J. - BILLIKOVÁ, M. 2018. Changes in the Rural Landscape and the Potential for its Renewal and Innovative Development. In Science of Youth 2018 - Proceedings of Reviewed Contributions, Nitra : SUA, 2018, pp. 104-114. ISBN 978-80-552-1844-1.

ŠTĚPÁNKOVÁ, R. - FERIANCOVÁ, Ĺ. 2011. Marks and Values of Folk Architecture in Present Rural Settlements. In Životné prostredie, vol. 45, 2011, no. 1, pp. 48-52.

TÓTH, A. - FERIANCOVÁ, L.. 2015. Dreviny pri objektoch drobnej sakrálnej architektúry vo vidieckej krajine. In Trendy v krajinotvorbe II. : zborník vedeckých príspevkov. Nitra : SPU, 2015, pp. 33-39. ISBN 978-80-552-1373-6.

TÓTH, A. - FERIANCOVÁ, L. 2016. Restoration of the Landscape Garden in Velká Maňa. In Acta Horticulturae et Regiotecturae, vol. 19, 2016, no. 1, pp. 1-3.

TÓTH, A. 2017. Small Sacral Architecture in the Context of Village and Micro-Region Development. In BARDKONTAKT 2017 - Problematika mestských pamiatkových centier : Pamiatky a pamiatkové územia v rozvojových programoch obcí a regiónov. Bardejov : Mesto Bardejov, 2017, pp. 212-217. ISBN 978-80-972776-7-3.

TÓTH, A. - VEREŠOVÁ, M. 2018. Small Sacral Architecture and Trees as Monuments in Diverse Cultural Landscapes of Slovakia. In Plants in Urban Areas and Landscape. Nitra : SUA, 2018, pp. 7-13. ISSN 2585-9811. ISBN 978-80-552-1829-8.

TROJANOWSKA, M. 2018. Sacred Places in Public Open Green Areas. In Teka Komisji Urbanistyki i Architektury Pan Oddział w Krakowie Urbanity and Architecture Files TOM, vol. XLVl, 2018, pp. 419-429.

TÜRK, K. H. 1979. Christliche Kleindenkmale in Börde und Neffeltal. Köln : Rheinland-Verlag, 1979, 240 p. ISBN 3-7927-0490-0.

VEREŠOVÁ, M. - SUPUKA, J. 2013. Changes of landscape structure and cultural values of vineyard landscape. In Acta Universitatis Agriculturae et Silviculturae Mendelianae Brunensis, vol. 61, 2013, pp. 1459-1470. ISSN 1211-8516.

VOŠKOVÁ, K. etal.2014.Sakrálne pamiatky v krajine: Banská Štiavnica a okolie. Bratislava : SUT, 2014, 165 p. ISBN 978-80-227-4308-2. 